\title{
GMINA ZRÓWNOWAŻONA ENERGETYCZNIE - STUDIUM PRZYPADKU WOJEWÓDZTWA ŚLĄSKIEGO
}

\begin{abstract}
Streszczenie
W artykule przestawiono rolę gospodarki energetycznej w zrównoważonym rozwoju gminy. Poddano analizie lokalne uwarunkowania planowania zrównoważonej gospodarki energetycznej w województwie śląskim oraz dokonano oceny działań gmin województwa w zakresie wdrażania zrównoważonego rozwoju energetycznego na ich terenie. W artykule wykorzystano wyniki badań ankietowych dotyczacych rozwoju rynku dóbr i usług ekologicznych w województwie, przeprowadzonych w 2012 roku, a także dane uzyskane w trakcie badania polityki wdrażania zrównoważonego rozwoju na szczeblu: krajowym, regionalnym i lokalnym w roku 2015.

Podstawowym wnioskiem, jaki nasuwa się po analizie, jest fakt, iż niewiele gmin województwa ślaskiego prowadzi kompleksowa politykę energetyczna, co powoduje, że polityka rozwoju prowadzona przez władze nie zawsze jest w stanie sprostać potrzebom gospodarki i zaspokajać potrzeby mieszkańców.
\end{abstract}

Słowa kluczowe: gmina, energia, zrównoważony rozwój, województwo śląskie

\section{ENERGETICALLY SUSTAINABLE MUNICIPALITY: THE CASE STUDY OF ŚLĄSKIE VOIVODESHIP}

\section{Summary}

The paper presents the significance of energy economy in the sustainable development of a municipality. It also analyzes the local determinants of sustainable energy planning in Sląskie Voivodeship. The author evaluates the activities of the local governments regarding the implementation of sustainable energy development in their area. The paper is based on the results of surveys concerning the development of the market for environmental goods and services in the region, conducted in 2012. Also presented are data obtained in the course of research on the implementation of sustainable development at national, regional and local level in the year 2015. The main conclusion of the research is that only a few municipalities of Ślaskie Voivodeship conduct a comprehensive energy policy, which means that the development policy run by the authorities is not always able to meet the needs of the local economy and residents.

Key words: municipality, energy, sustainable development, Śląskie Voivodeship

JEL: Q42; Q48 


\section{Wstęp}

Gospodarka energetyczna to kluczowy element rozwoju gospodarczego, który zajmuje istotne miejsce w polityce energetycznej państwa i regionu. Planowanie gospodarki energetycznej w gminie stanowi podstawę do kreowania zrównoważonego rozwoju oraz ładu energetycznego na jej terenie. Prowadzenie efektywnej gospodarki energetycznej obejmuje wiele obszarów, na które składa się: planowanie energetyczne, dążenie do zwiększenia efektywności energetycznej i korzystanie z instrumentów wolnego rynku energii. Strategie rozwoju energetycznego, przyjmowane przez gminy, mają zapewnić racjonalizację ich wykorzystania, a także określać konieczne kierunki działań związanych z zarządzaniem nimi. W samorządach gminnych drzemie potencjał w zakresie poprawy efektywności energetycznej i wykorzystania zasobów lokalnych źródeł energii, dlatego świadome prowadzenie zrównoważonej polityki energetycznej będzie pozytywnie wpływać na bezpieczeństwo energetyczne gminy, jak również pozwoli na ograniczenie niskiej emisji. Prowadzenie zrównoważonej polityki energetycznej ma szczególne znaczenie dla gmin województwa śląskiego. Województwo śląskie cechuje się największym zużyciem energii elektrycznej ogółem oraz w przeliczeniu na jednego mieszkańca. Ponadto, boryka się z różnymi problemami środowiskowymi, z których warto przynajmniej wspomnieć największe zanieczyszczenie powietrza w skali kraju. Stąd racjonalne działania gmin w zakresie gospodarki energetycznej pozwola zapoczątkować konkurencyjną, innowacyjną i niskoemisyjną gospodarkę, wspierając rozwój ekonomiczny Polski na arenie międzynarodowej, przy jednoczesnym zachowaniu walorów środowiska przyrodniczego. Celem opracowania jest charakterystyka lokalnych uwarunkowań planowania zrównoważonej gospodarki energetycznej w województwie śląskim oraz ocena działań gmin województwa w zakresie wdrażania zrównoważonego rozwoju energetycznego na ich terenie.

Metodami badawczymi, na których opiera się artykuł, są analiza dokumentów strategicznych i danych statystycznych związanych z gospodarowaniem energią w województwie śląskim, a przede wszystkim analiza porównawcza wyników następujących badań statutowych, w których autorka brała udział: Katedry Zarządzania Ochroną Środowiska Uniwersytetu Ekonomicznego w Katowicach przeprowadzonych w 2012 roku i dotyczących rozwoju rynku dóbr i usług ekologicznych w województwie oraz Katedry Polityki Społecznej i Gospodarczej tegoż uniwersytetu przeprowadzonych w 2015 roku i obejmujących politykę zrównoważonego rozwoju na szczeblu: krajowym, regionalnym i lokalnym. Zarówno w 2012 roku, jak i 2015 roku ankieta została skierowana do wszystkich 167 gmin województwa i zawierała między innymi pytania związane z lokalną polityką energetyczną prowadzona przez samorządy. Zwrotność ankiet kształtowała się na poziomie 42\% (70 gmin odpowiedziało) w 2012 roku oraz 65\% (108 gmin odpowiedziało) w 2015 roku. 


\section{Planowanie zrównoważonej gospodarki energetycznej w wymiarze lokalnym}

Planowanie zrównoważonej gospodarki energetycznej obejmuje wszystkie szczeble administracji publicznej. Aktywne włączanie się władz samorządowych w realizację celów polityki energetycznej ma ogromne znaczenie dla rozwoju energetyki odnawialnej. To właśnie na poziomie regionalnym i lokalnym zapada większość decyzji dotycząca OZE, począwszy od planowania, udzielania decyzji administracyjnych, na wsparciu finansowym kończąc. Równocześnie poziom regionu jest kluczowy pod względem: budowania świadomości społecznej, mobilizowania władz lokalnych, tworzenia klastrów energii odnawialnej i innych. Jednocześnie niezwykle ważna jest umiejętność zarządzania zmiana, która polega na przejściu od scentralizowanej energetyki konwencjonalnej do zdecentralizowanej energetyki rozproszonej bazującej na wykorzystaniu odnawialnych zasobów energii. Jest to związane nie tylko z planowaniem energetycznym, ale także z planowaniem przestrzennym i umiejętnością uwzględniania kwestii energetycznych i lokalnego wykorzystania odnawialnych zasobów energii w strategiach rozwoju województw. Niezbędne zatem staje się: opracowanie stosownych zapisów w strategiach sporządzanych przez władze samorządowe, wprowadzanie systemowego zarządzania gospodarką energetyczną w jednostce terytorialnej oraz szczegółowe opracowanie planów wydatków inwestycyjnych w obszarze energetyki.

Niestety, w chwili obecnej województwo śląskie nadal nie posiada kompleksowej, wielopłaszczyznowej strategii rozwoju energetyki na terenie województwa. Stosowne zapisy, dotyczące tego obszaru, znajdują się w dokumencie Strategia Rozwoju Województwa Ślaskiego - „Ślaskie 2020+”, gdzie wśród podstawowych wyzwań polityki rozwoju województwa wskazano m.in.:

- unowocześnienie sektora energetycznego i dywersyfikację źródeł wytwarzania energii elektrycznej;

- redukcję emisji pyłowych i gazowych zanieczyszczeń powietrza;

- ograniczanie negatywnego oddziaływania energetyki na środowisko i zwiększenie poziomu lokalnego wykorzystywania odnawialnych źródeł energii;

- rozwój i upowszechnienie zastosowania technologii energooszczędnych w regionie.

W dokumencie tym w ramach celu operacyjnego C.1. Zrównoważone wykoraystanie zasobów środowiska wśród kierunków działań uwzględniono wspieranie rozwiązań ograniczających niską emisję oraz zużycie zasobów środowiska i energii w: przedsiębiorstwach, gospodarstwach domowych, obiektach i przestrzeni użyteczności publicznej, jak również wspieranie modernizacji infrastruktury energetycznej oraz rozwoju energetyki opartej na odnawialnych źródłach energii przy minimalizacji kosztów środowiskowych i krajobrazowych. Szkoda, że nie skonkretyzowano sposobów realizacji tych działań, a założono jedynie wzrost udziału energii pochodzących z OZE w zużyciu energii elektrycznej ogółem z 6,3\% (wartości bazowa z 2011 roku) do 15\% jako wartości docelowej w 2020 roku. Warto zwrócić uwagę, iż w Strategii „Ślaskie 2020+” przyjęto opracowanie dokumentów dziedzinowych i branżowych, w tym także związanych z zastosowaniem odnawialnych źródeł energii i polityki energetycznej województwa, 
a zarazem z efektywnością energetyczną, które mają rozwinąć cele i kierunki działań zawartych w strategii województwa i w rezultacie będą stanowić kluczowy element jej systemu wdrażania. Pomimo przyjęcia dokumentu w 2013 roku, do chwili obecnej nie opracowano stosownych dokumentów, co utrudnia prowadzenie gospodarki zrównoważonej energetycznie na terenie województwa.

Zapisy, które odnoszą się do prowadzenia racjonalnej gospodarki energetycznej łączącej efektywność energetyczną z nowoczesnymi technologiami oraz budowania gospodarki niskoemisyjnej w województwie, również znajdują się w takich dokumentach regionalnych, jak: Program Ochrony Środowiska dla Województwa Ślaskiego do roku 2019 z. unvaglednieniem perspektywy do roku 2024, Projekt Planu Zagospodarowania Przestrzennego Województwa Ślaskiego „Plan 2020+”, Program Ocbrony Powietrza dla terenu Województwa Ślaskiego majacy na celu osiagniecie poziomón dopuszczalnych i docelonych substancii w powietrzu oraz.pułapu stęienia eksposycji, a także w założeniach programowych do Polityki Gospodarki Niskoemisyjnej dla Wojewódz̨twa Ślaskiego. Ten ostatni dokument, uchwalony w 2016 roku, jest odpowiedzią na wytyczne Unii Europejskiej zawarte w pakiecie energetycznoklimatycznym, tj.: zmniejszenie emisji gazów cieplarnianych o 20\% do 2020 roku (w porównaniu z rokiem bazowym 1990), zwiększenie udziału energii ze źródeł odnawialnych w zużycie energii końcowej do 20\% (w tym 10\% udziału biopaliw w transporcie) oraz zwiększenie efektywności wykorzystania energii o 20\%. Ponadto, nawiązuje do celów wynikających z projektu Narodowego Programu Gospodarki Niskoemisyjnej, takich jak:

- niskoemisyjne wytwarzanie energii;

- poprawa efektywności gospodarowania surowcami i materiałami, w tym odpadami;

- rozwój zrównoważonej produkcji obejmującej: przemysł, budownictwo i rolnictwo;

- transformacja niskoemisyjna w dystrybucji i mobilności;

- promocja wzorców zrównoważonej konsumpcji.

Jednocześnie na uwagę zasługuje Program wykeoryystania odnawialnych źródet energii na obszarach nieprzemysłowych wojewódžtwa ślaskiego, mimo że został on przyjęty przez Sejmik Województwa Śląskiego w 2007 roku, jest jedynym, zbiorczym opracowaniem zawierającym charakterystykę poszczególnych obszarów województwa w zakresie posiadanego i dostępnego potencjału energii odnawialnej, przy aktualnym poziomie technicznych i technologicznych możliwości ich wykorzystania. W programie omówiono zarazem korzyści: ekologiczne, ekonomiczne i społeczne związane z zastępowaniem konwencjonalnych źródeł energii źródłami odnawialnymi. Niestety, program swoim zakresem obejmuje obszary nieuprzemysłowione województwa, stąd podejście do procesu planowania regionalnej energetyki przez władze samorządowe należy ocenić jako krótkowzroczne. W wyniku pominięcia w programie najbardziej zurbanizowanego, centralnego obszaru regionu, władze województwa zakładają dalsze uzależnienie od energetyki opartej na węglu, co jest szczególnie niekorzystne ze względu na stan środowiska na tym obszarze [Lorek, 2014, s. 223]. 


\section{Wdrażanie zrównoważonego rozwoju energetycznego w praktyce śląskich gmin}

Zrównoważony rozwój energetyczny trudno jednoznacznie zdefiniować. Tymczasem przez ten powinno się rozumieć taki sposób gospodarowania energia, który zapewni dostęp do wystarczającej ilości energii dla obecnie żyjącego i przyszłych pokoleń oraz będzie nastawiony na minimalizowanie negatywnych oddziaływań środowiskowych w skali lokalnej i globalnej. Realizacji tych celów służy podjęcie działań w kierunku zwiększenia udziału w bilansie energetycznym odnawialnych źródeł energii, takich jak: biomasa, energia wiatru, promieniowania słonecznego, energia odpadowa, a także zwiększenie efektywności wykorzystania energii. Zatem podstawowym celem zrównoważonej polityki energetycznej jest ograniczenie skutków negatywnego oddziaływania energetyki na atmosfere przez m.in.: wspieranie polityki i przedsięwzięć prowadzących do wykorzystania bezpiecznej dla środowiska i opłacalnej dla gospodarki energii z niekonwencjonalnych odnawialnych źródeł, mniej szkodliwej i bardziej wydajnej produkcji energii, jej przesyłania, dystrybucji i wykorzystania, jak również do utrzymania równowagi pomiędzy: bezpieczeństwem energetycznym, zaspokojeniem potrzeb społecznych, konkurencyjnościa gospodarki a ochroną środowiska [Lorek 2007, s. 163-176].

Efektywne kształtowanie lokalnej gospodarki energetycznej to zarówno możliwości, jak i wyzwanie w stosunku do podstawowych jednostek samorządu terytorialnego. W gminach realizacja zadań z obszaru energetyki jest jednym z przejawów gospodarki komunalnej, która ma na celu zaspokojenie potrzeb wspólnoty samorządowej. Obowiązki, które nakłada prawo energetyczne na gminy, wpisują się w politykę energetyczną całego kraju, a ich realizacja skutkuje powstaniem wielostronnego systemu zależności energetycznych na linii podaż - przesył - popyt. Ustawa Prawo energetyczne wskazuje cztery podstawowe zadania gmin w zakresie zapotrzebowania i wykorzystywania energii i paliw. Jako pierwsze zadanie zostało określone planowanie i organizacja zaopatrzenia w: ciepło, energię elektryczną i paliwa gazowe. Realizując je, gmina umożliwia bieżące dostawy mediów energetycznych, a planowanie zaopatrzenia obejmuje zarówno wybór podmiotów trudniących się ich wytwarzaniem, jak i infrastruktury niezbędnej do przesyłu tych mediów do odbiorców końcowych. Kolejne zadanie to planowanie oświetlenia miejsc publicznych i dróg znajdujących się na terenie gminy. Poza względami bezpieczeństwa związanymi z poruszaniem się osób czy pojazdów, obowiązek ten ma również pozwolić m.in. na zwiększenie atrakcyjności danych obszarów dla dalszej urbanizacji i industrializacji. Kolejnym z punktów ustawy jest finansowanie oświetlenia: ulic, placów i dróg publicznych na terenie gminy. To zadanie bezpośrednio łączy się z zapisami Ustawy z dnia 11 kwietnia 2011 roku o efektywności energetycznej, w której zdefiniowano dodatkowe zadania dla gmin, natomiast te odnoszą się do poprawy charakterystyki energetycznej budynków będących własnością lub zarządzanych przez jednostkę samorządu terytorialnego, a także do zakupu energooszczędnych urządzeń biurowych i pojazdów. Czwarte zadanie, które obowiązuje od 1 stycznia 2012 roku, to planowanie i organizacja działań mających na celu racjonalizację zużycia energii i promocję rozwiązań zmniejszających jej wykorzystywanie. Pojawienie się tego obowiązku w Prawie energetycznym jest wynikiem ustaleń zawartych w Polityce Energetycznej Polski do 2030 roku, 
która została przyjęta w uchwale Rady Ministrów w dniu 10 listopada 2010 roku. Jednym z jej głównych celów jest zagwarantowanie takiego rozwoju gospodarczego, który nie będzie powodował wzrostu zapotrzebowania na energię pierwotna.

Działaniem, które bezpośrednio nie zostało wymienione przez ustawy, a może potencjalnie przełożyć się na obniżenie kosztów energii, jest tzw. zarządzanie kosztami energii, polegające na organizacji przetargów na dostawy energii dla większej grupy odbiorców, którymi mogą być jednostki pomocnicze samorządu bądź nawet grupa lub stowarzyszenie gmin. Jednocześnie bardzo ważnym zadaniem każdej gminy jest ochrona środowiska i przyrody. Obszar ten jest ściśle powiązany z gospodarką energetyczną w gminach, w związku z tym niezwykle istotnym jest, aby w długookresowych strategiach samorządów lokalnych zostały uwzględnione oba elementy i ich wzajemne oddziaływanie. Niezbędnym czynnikiem, potrzebnym do zachowania równowagi między oboma obszarami, jest prawidłowe zarządzanie gospodarką energetyczną [Głębocki, Herbuś, 2016, s. 148-149].

Realizacja tych zadań przez gminę powinna odbywać się według dwóch planów. Po pierwsze, zgodnie z miejscowym planem zagospodarowania przestrzennego. Jeśli jednak w gminie nie ma takiego planu, wspomniane zadania należy realizować według kierunków rozwoju gminy zawartych w studium uwarunkowań i kierunków zagospodarowania przestrzennego gminy. Po drugie, zgodnie $z$ wojewódzkim programem ochrony powietrza przyjętym na podstawie art. 91 Ustawy z 27 kwietnia 2001 roku Prawo ochrony środowiska.

Wdrażając zadania związane $z$ energetyka, wójt, burmistrz lub prezydent miasta opracowuje projekt założeń do planu zaopatrzenia w: ciepło, energię elektryczną i paliwa gazowe, który sporządza się dla obszaru gminy na co najmniej 15 lat i aktualizuje co najmniej raz na trzy lata. Ponadto, pierwsze założenia do planu powinny zostać uchwalone przez władze gminne w terminie 2 lat od dnia wejścia w życie ustawy zmieniającej, czyli do 11 marca 2012 roku. Przepisy prawa energetycznego nie zawieraja jednak sankcji dla władz gmin za brak zastosowania się do tych przepisów.

W przeprowadzonych badaniach, mimo że większość gmin w województwie śląskim (92\% badanych w 2012 roku i 89,7\% w 2015 roku) posiada Miejscony plan ragospodarowania przestrzennego, jedynie 36\% gmin w 2015 roku opracowało (37\% w 2012 roku) Plan zaopatrzenia w ciepto, energie elektryczna i paliwa gazowe lub założenia do tego planu. Co więcej, niepokojące jest to, iż równocześnie jedynie 10\% badanych gmin deklaruje prowadzenie prac mających na celu opracowanie tego dokumentu. Zgodnie z przepisami prawa energetycznego, projekt założeń powinien określać: ocenę stanu aktualnego i przewidywanych zmian zapotrzebowania na energię, przedsięwzięcia racjonalizujące użytkowanie energii, możliwości wykorzystania istniejących nadwyżek i lokalnych zasobów paliw i energii, z uwzględnieniem odnawialnych źródeł energii, energii elektrycznej i ciepła użytkowego wytwarzanych w kogeneracji oraz zagospodarowania ciepła odpadowego z instalacji przemysłowych, a także zakres współpracy z innymi gminami. Gminy, które nie dopełniły obowiazzku ustawowego opracowania planu, nie moga prowadzić efektywnej gospodarki energetycznej na terenie gminy, takiej, która jest w stanie sprostać potrzebom rozwijającej się gospodarki i oczekiwaniom społecznym. 
Niewielki (12,9\%) odsetek respondentów uczestniczących w badaniu w 2015 roku posiadało również opracowany Plan ograniczenia niskiej emisji. Natomiast, jeśli chodzi o Plan roz̧woju alternatymmych źródeł energii, ankietowane gminy w większości nie wykazały zainteresowania tym obszarem działalności. W chwili obecnej jedynie 7,4\% gmin województwa śląskiego już posiada ten dokument strategiczny, a tylko 4,6\% planuje jego opracowanie. Należy tutaj zaznaczyć, iż w stosunku do roku 2012 roku nastapił nieznaczny wzrost gmin planujących rozwój OZE na terenie gminy, gdyż w poprzedniej edycji badań tylko $2,8 \%$ gmin deklarowało posiadanie tego planu, lecz to nie napawa optymizmem.

Niewiele gmin dokonało oceny istniejącego stanu zapotrzebowania na ciepło, energię i paliwa gazowe oraz wytyczyło kierunki zmian w tym zakresie uwzględniające przedsięwzięcia racjonalizujące użytkowanie paliw i energii, a także możliwości wykorzystania lokalnych zasobów paliw i energii, stąd tylko w niewielkim stopniu zostały spożytkowane przez gminy możliwości kompleksowej regulacji gospodarki energetycznej na lokalnych rynkach. Usprawiedliwieniem zaniechania działań pod tym względem nie może być stwierdzenie, iż planowanie potrzeb energetycznych, zwłaszcza w długim okresie, jest obarczone ryzykiem niepewności co do czynników wpływających na poziom zapotrzebowania energetycznego, zwłaszcza że zadania planistyczne, dotyczące sfery energetyki, należą do najistotniejszych zadań własnych gminy o charakterze obligatoryjnym, z których gmina nie może się zwolnić.

Racjonalne prowadzenie gospodarki energetycznej na szczeblu gminnym wymaga w pierwszej kolejności ustalenia celów, które powinny być osiagnięte dzięki polityce energetycznej prowadzonej na poziomie lokalnym. Jak pokazują dotychczasowe doświadczenia, praktyka planowania energetycznego przez gminy sprowadza się do opracowania planów jako zbioru działań narzuconych przez ustawową strukturę założeń do planu i planu zaopatrzenia w energię. Co ciekawe, choć 53\% badanych gmin w 2015 roku odpowiedziało twierdzaco na pytanie o opracowanie celów zrównoważonego rozwoju w strategiach gminnych, to w momencie ich wyartykułowania przeważały wskazania celów społecznych lub ogólnogospodarczych w prawie wszystkich badanych gminach. Kwestie gospodarowania energia zostały przesunięte na dalszy plan i pojawiły się jako odwzorowanie założeń strategii rozwoju województwa jedynie w ogólnikowych stwierdzeniach, a mianowicie: zmniejszenia energochłonności i emisji zanieczyszczeń do atmosfery, polepszenia jakości powietrza czy też rozwoju odnawialnych źródeł pozyskiwania energii. Pomijając fakt, iż $\mathrm{w}$ gminnych strategiach rozwoju dominuje niezrównoważenie poszczególnych ładów w obrębie programowania konkretnych celów, to planowanie energetyczne prawie w ogóle w nich nie istnieje. Takie podejście kłóci się z wynikami uzyskanymi w dalszym toku badań. Respondentów zapytano bowiem o wskazanie priorytetowych obszarów w ramach rozwoju usług publicznych świadczonych przez same gminy lub na ich zlecenie, jak również polityki władz lokalnych stymulującej rozwój rynku dóbr i usług ekologicznych na ich obszarze. Chociaż większość ankietowanych gmin na pierwszych miejscach uznała gospodarkę wodno-ściekowa, transport oraz gospodarkę odpadami za priorytetowe, to, jak pokazują dane zawarte w tabeli 1., obszary dotyczące gospodarowania energia znalazły się w czołówce wskazań jako ważne i bardzo ważne dla gmin. Jedynym wyjątkiem były kwestie związane 
z budownictwem energooszczędnym, gdzie większość gmin wskazała ten obszar jako drugorzędny w 2012 roku lub dość ważny w 2015 roku.

TABELA 1.

Hierarchia ważności pozycjonowania usług w zakresie gospodarowania energią w gminach województwa śląskiego, według opinii respondentów (w \% ważnych wskazań)

\begin{tabular}{|c|c|c|c|c|c|c|c|c|c|c|c|c|}
\hline \multirow{2}{*}{$\begin{array}{c}\text { Rodzaj/ } \\
\text { obszar usług }\end{array}$} & \multicolumn{2}{|c|}{ Priorytetowe } & \multicolumn{2}{|c|}{$\begin{array}{l}\text { Bardzo } \\
\text { ważne }\end{array}$} & \multicolumn{2}{|c|}{ Ważne } & \multicolumn{2}{|c|}{$\begin{array}{c}\text { Dość } \\
\text { ważne }\end{array}$} & \multicolumn{2}{|c|}{ Drugorzędne } & \multicolumn{2}{|c|}{ Nieistotne } \\
\hline & 2012 & 2015 & 2012 & 2015 & 2012 & 2015 & 2012 & 2015 & 2012 & 2015 & 2012 & 2015 \\
\hline $\begin{array}{l}\text { Ochrona } \\
\text { powietrza }\end{array}$ & 11,5 & 18,5 & 42,6 & 42,5 & 31,1 & 28,7 & 11,5 & 7,4 & 3,3 & 0,9 & 0,0 & 0,0 \\
\hline $\begin{array}{l}\text { Budownictwo } \\
\text { ekologiczne }\end{array}$ & 0,0 & 0,0 & 7,5 & 5,5 & 22,6 & 22,2 & 22,6 & 38,8 & 35,8 & 22,2 & 11,3 & 2,7 \\
\hline $\begin{array}{l}\text { Alternatywne } \\
\text { źródła energii* }\end{array}$ & & 4,6 & & 23,1 & & 41,6 & & 15,7 & & 9,2 & & 0,9 \\
\hline $\begin{array}{l}\text { Poprawa efek- } \\
\text { tywności ener- } \\
\text { getycznej* }\end{array}$ & 3,3 & 7,4 & 10,0 & 25,9 & 43,3 & 41,6 & 33,3 & 11,1 & 8,3 & 5,5 & 1,7 & 0,9 \\
\hline
\end{tabular}

* Alternatywne źródła energii i poprawa efektywności energetycznej były potraktowane łącznie w badaniach, które miały miejsce w 2012 roku, stąd dane dla tych obszarów przedstawiono w tabeli jako jedną wspólną pozycję.

Źródło: opracowanie własne.

Według uzyskanych wyników, fundamentalną zmianą, jaka dokonała się wśród badanych gmin, jest przeniesienie ciężaru istotności zagadnień w obszarze dotyczącym rozwoju alternatywnych źródeł energii i poprawy efektywności energetycznej. Mianowicie, stopień istotności przesunął się pomiędzy rokiem 2012 a 2015 z poziomu dość ważne i ważne na poziom ważne i bardzo ważne. Co prawda, wszelkie dostępne opracowania określają możliwości wykorzystania energii: słonecznej, geotermalnej, wodnej i wiatrowej w województwie śląskim jako „przeciętne” [por. Program Ochrony Środowiska dla województwa ślaskiego..., 2015, s. 200 i dalsze; Określenie potencjału energetycznego..., 2011; Rynek odnawialnych źródeł energii..., 2013], to stanowią one potencjał wskazywany jako teoretyczny, a z uwagi na trudności oceny rzeczywistego stopnia wykorzystania OZE ze względu na rozproszenie i brak kompletnych danych, potencjał rozwoju odnawialnych źródeł energii na terenie województwa zależy przede wszystkim od: świadomości ekologicznej mieszkańców, dostępności programów wsparcia i obecności producentów instalacji OZE.

Województwo śląskie, podobnie jak pozostałe województwa w kraju, nadal charakteryzuje się niewielkim udziałem OZE w produkcji energii elektrycznej ogółem. Zgodnie z danymi Banku Danych Lokalnych, udział ten w 2014 roku (ostatnie dostępne dane) wynosił 6,6\%, osiagając poziom produkcji zielonej energii wynoszący 1 761,5 GWh, przy całkowitej produkcji energii elektrycznej na poziomie 26 608,0 GWh. Według danych URE, w województwie znajduje się 175 instalacji produkujących energię elektryczną 
ze źródeł odnawialnych na dużą skalę, o łącznej mocy 180042 MW. Na przestrzeni kilku ostatnich lat można zauważyć tendencję wzrostową zarówno wzrostu liczby instalacji, jak i zużycia energii pozyskanej ze źródeł energii odnawialnych (gdzie dominują gospodarstwa domowe).

Ze względu na niewielki stopień wykorzystania potencjału OZE w regionie, niezwykle ważna jest promocja i systemy wsparcia, jakie gmina może zapewnić mieszkańcom w realizacji inwestycji tak o małej, jak i wielkiej skali. Niezbędna staje się w tym przypadku zmiana świadomości władz samorządowych oraz przekonanie ich przedstawicieli o celach i możliwościach wpływu na kształtowanie zrównoważonej gospodarki energetycznej. Zachętą do bardziej aktywnych postaw samorządów gminnych jest wskazanie korzyści, jakie gmina może czerpać z rozwijania alternatywnych źródeł energii, począwszy od korzyści ekonomicznych i ekologicznych, wśród których chociażby należy wymienić: regionalny rozwój gospodarczy, dywersyfikację źródła dochodów dla producentów i rolników z regionu, dodatkowe miejsca pracy, możliwość skorzystania ze środków pomocowych czy też wzrost bezpieczeństwa energetycznego regionu, zmniejszenie emisji gazów cieplarnianych do atmosfery, redukcję zanieczyszczeń wody, emisji dwutlenku węgla oraz redukcję ilości wytwarzanych odpadów aż po stworzenie proekologicznego wizerunku regionu.

Jak wynika z tabeli 1., również na przestrzeni lat 2012-2015 zwiększył się o 7 p. p. udział działań gmin w obszarze ochrony powietrza, postrzeganych jako priorytetowe (z 11,5\% do 18,5\%). Wynika to z dostrzeżenia przez władze gminy pogłębiającego się problemu zanieczyszczenia powietrza i niskiej emisji w znacznym stopniu występującej na terenie województwa. W 2015 roku ponad 77\% badanych gmin stwierdziło, iz problem niskiej emisji często ma miejsce na terenie gminy. Rysunek 1. pokazuje procentowy rozkład gmin, które zauważyły występowanie tego problemu na swoim terenie. Zgodnie z danymi zawartymi w założeniach programowych do Polityki Gospodarki Niskoemisyjnej dla Województwa Ślaskiego, jeśli chodzi o jakość powietrza, to województwo ślaskie należy do najbardziej zanieczyszczonych w kraju (40\% udziału emisji w skali kraju ma tutaj swoje źródło). Od wielu lat w regionie są przekraczane dopuszczalne poziomy stężeń: pyłu zawieszonego PM10 i PM2,5, benzo(a)pirenu, dwutlenku siarki, dwutlenku azotu i ozonu. W 2014 roku pod względem ilości wyemitowanych zanieczyszczeń pyłowych województwo śląskie uplasowało się na pierwszym miejscu wśród pozostałych województw - emisja zanieczyszczeń pyłowych stanowiła 21,7\% emisji pyłów w Polsce [Zato:̇enia programowe..., 2016, s. 70]. 
RYSUNEK 1.

Występowanie niskiej emisji z domów mieszkalnych na terenie badanych gmin województwa śląskiego w 2015 roku (\% ważnych odpowiedzi)

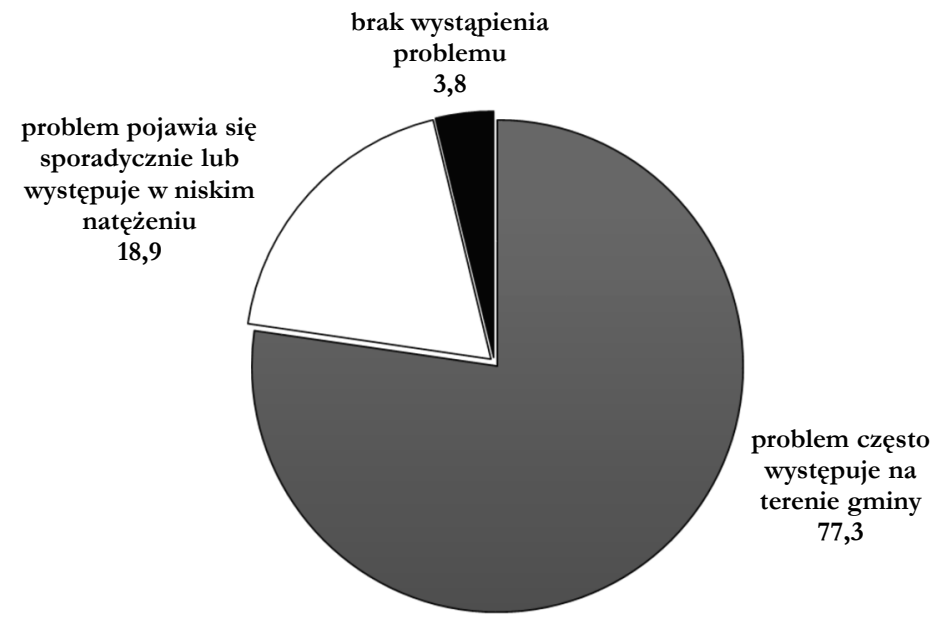

Źródło: opracowanie własne.

Przyczyną występowania niskiej emisji jest głównie spalanie paliw stałych w nieefektywnych energetycznie i wysokoemisyjnych urządzeniach grzewczych małej mocy, często połączone $z$ wysokim zapotrzebowaniem na ciepło pomieszczeń mieszkalnych, zwłaszcza w starych budynkach wykonanych przestarzała techniką budowlana. Ponadto, sytuacji nie ułatwia brak krajowych uregulowań prawnych w stosunku do standardów emisji z instalacji spalania paliw stałych o mocy poniżej 1 MW czy też brak uregulowań w odniesieniu do jakości paliw stałych, przede wszystkim węgla. Co więcej, wiąże się z tym jeszcze niska świadomość społeczna o wysokiej szkodliwości zanieczyszczeń, pochodzących ze ,złego” spalania paliw stałych, dla zdrowia ludzi i środowiska oraz zła polityka informacyjna dotycząca możliwości wykorzystania nowoczesnych technologii i wreszcie uwarunkowania ekonomiczne mieszkańców gminy, których po prostu nie stać na zmianę sposobu ogrzewania [Niska emisja - sprawa wysokiej wagi]. Samorządy starają się walczyć z zanieczyszczeniem powietrza i podejmują inicjatywy, które mają na celu likwidację niskiej emisji. Jak pokazuje wykres 2., również włodarze ankietowanych gmin w przeważającej części (70\% wskazań) wykazują realizację przez gminę projektów dotyczących zmiany sposobu ogrzewania lub termomodernizacji, a także projektów podnoszących efektywność energetyczną na terenie gminy (48\%). Równocześnie 43\% gmin nie podejmuje żadnych projektów związanych z gospodarką energetyczną na terenie gminy. Wartym podkreślenia jest fakt, iż gminy, które w nowej perspektywie finansowej Unii Europejskiej 2014-2020 chca pozyskać pieniądze m.in. na działania w zakresie termomodernizacji budynków czy wykorzystania OZE, muszą posiadać plany gospodarki niskoemisyjnej. W 2015 roku WFOŚiGW w Katowicach przyznał 30 gminom z wo- 
jewództwa śląskiego dotację (w łącznej kwocie 765 tys. zł) na opracowanie planów gospodarki niskoemisyjnej, co zważywszy na niski odsetek gmin posiadających taki dokument, jest krokiem w kierunku kształtowania optymalnej lokalnej gospodarki energetycznej.

RYSUNEK 2.

\section{Realizacja projektów dotyczących gospodarki energetycznej w ankietowanych} gminach w 2015 roku (\% ważnych odpowiedzi)

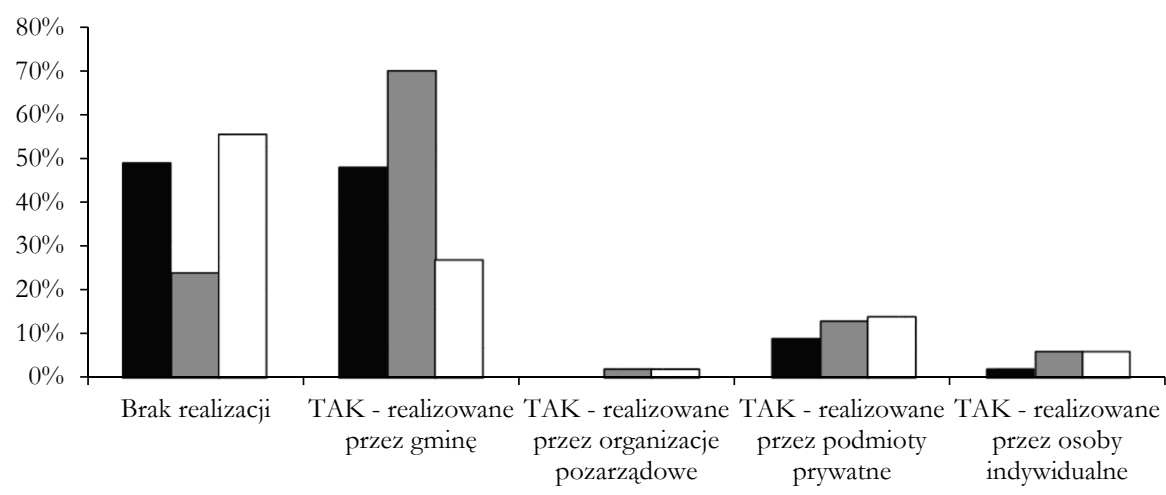

$$
\begin{aligned}
& \square \text { Poprawa efektywności energetycznej } \\
& \square \text { Zmiana sposobu ogrzewania i/lub termomodernizacja } \\
& \square \text { Budowa OZE }
\end{aligned}
$$

Źródło: opracowanie własne.

Badane gminy zapytano również o poziom zaawansowania działań w zakresie gospodarowania energia. Ze względu na ograniczone środki własne gmin, które mogą być przeznaczone na cele związane z realizacją zrównoważonej gospodarki energetycznej oraz niespójność, niejasność i częste zmiany przepisów (te bariery w prowadzeniu skutecznej polityki energetycznej najczęściej podawali respondenci) nie dziwi średnio zaawansowany lub początkujący stopień ich realizacji wskazany przez gminy (por. tabela 2.). Ankietowane gminy równocześnie wypowiedziały się w kwestii kierunków prowadzenia inwestycji. Z uzyskanych danych wynika, iż gminy najczęściej inwestują w zmianę sposobu ogrzewania, czego wyrazem są udzielane dotacje do instalacji solarnych i pomp ciepła, a także działania wspierające wymianę kotłów c.o. na bardziej efektywne. Ponadto, gminy realizują także zadania związane z termomodernizacją budynków użyteczności publicznej i inwestują w budowę takich przedsięwzięć wspierających rozwój OZE, jak budowa biogazowi. Jednocześnie ankietowani deklarowali działania mające na celu montaż energooszczędnego oświetlenia ulicznego. Działania te w 2015 roku były głównie finansowane: ze środków własnych (choć w mniejszym stopniu niż w roku 2012), środków Narodowego (NFOŚiGW) lub Wojewódzkiego Funduszu Ochrony Środowiska i Gospodarki Wodnej (WFOŚiGW), a w mniejszej części ze środków komercyjnych czy w ramach partnerstwa publiczno-prywatnego (tabela 3.). 
TABELA 2.

Poziom zaawansowania realizowanych działań w zakresie gospodarki energią w gminach województwa śląskiego (w \% ważnych wskazań)

\begin{tabular}{|c|c|c|c|c|c|c|c|c|c|c|}
\hline \multirow{2}{*}{$\begin{array}{c}\text { Rodzaj/ } \\
\text { obszar usług }\end{array}$} & \multicolumn{2}{|c|}{$\begin{array}{l}\text { Bardzo zaa- } \\
\text { wansowane }\end{array}$} & \multicolumn{2}{|c|}{$\begin{array}{l}\text { Średnio zaa- } \\
\text { wansowane }\end{array}$} & \multicolumn{2}{|c|}{ Początkujące } & \multicolumn{2}{|c|}{ Pilotażowe } & \multicolumn{2}{|c|}{ Brak działań } \\
\hline & 2012 & 2015 & 2012 & 2015 & 2012 & 2015 & 2012 & 2015 & 2012 & 2015 \\
\hline Ochrona powietrza & 12,8 & 14,8 & 45,7 & 50,0 & 18,5 & 19,4 & 2,8 & 3,7 & 5,7 & 9,2 \\
\hline $\begin{array}{l}\text { Budownictwo eko- } \\
\text { logiczne }\end{array}$ & 2,8 & 2,7 & 12,8 & 24,2 & 15,7 & 28,7 & 12,8 & 7,4 & 37,1 & 40,7 \\
\hline $\begin{array}{l}\text { Zmiany sposobu } \\
\text { ogrzewania i/lub } \\
\text { termomodernizacja }\end{array}$ & b.d. & 25,9 & b.d. & 52,7 & b.d. & 12,9 & b.d. & 0,0 & b.d. & 7,4 \\
\hline $\begin{array}{l}\text { Alternatywne źró- } \\
\text { dła energii* }\end{array}$ & \multirow{2}{*}{7,1} & 4,6 & \multirow{2}{*}{25,7} & 25,9 & \multirow{2}{*}{30,0} & 38,8 & \multirow{2}{*}{14,2} & 9,2 & \multirow{2}{*}{12,8} & 18,5 \\
\hline $\begin{array}{l}\text { Poprawa efektyw- } \\
\text { ności energetycznej* }\end{array}$ & & 7,4 & & 33,3 & & 33,3 & & 9,2 & & 12,0 \\
\hline
\end{tabular}

* Alternatywne źródła energii oraz poprawa efektywności energetycznej były potraktowane łącznie w badaniach mających miejsce w 2012 roku, stąd dane dla tych obszarów przedstawiono w tabeli jako jedną wspólną pozycję.

b. d. - brak danych

Źródło: opracowanie własne.

TABELA 3.

Źródła finansowania realizowanych zadań inwestycyjnych w zakresie gospodarki energią w gminach województwa śląskiego (w \% ważnych wskazań)

\begin{tabular}{|c|c|c|c|c|c|c|c|c|c|c|c|c|}
\hline \multirow[t]{2}{*}{$\begin{array}{c}\text { Rodzaj/obszar } \\
\text { usług }\end{array}$} & \multicolumn{2}{|c|}{$\begin{array}{l}\text { Środki } \\
\text { własne }\end{array}$} & \multicolumn{2}{|c|}{$\begin{array}{l}\text { NFOŚiGW } \\
\text { lub } \\
\text { WFOŚiGW }\end{array}$} & \multicolumn{2}{|c|}{$\begin{array}{c}\text { Fundusze } \\
\text { UE }\end{array}$} & \multicolumn{2}{|c|}{$\begin{array}{c}\text { Środki } \\
\text { komercyjne }\end{array}$} & \multicolumn{2}{|c|}{ PPP } & \multicolumn{2}{|c|}{ Inne } \\
\hline & 2012 & 2015 & 2012 & 2015 & 2012 & 2015 & 2012 & 2015 & 2012 & 2015 & 2012 & 2015 \\
\hline Ochrona powietrza & 84,6 & 50,0 & 74,4 & 47,2 & 15,4 & 44,4 & 7,7 & 4,6 & b.d. & 0,0 & 10,3 & 4,6 \\
\hline $\begin{array}{l}\text { Budownictwo ekolo- } \\
\text { giczne }\end{array}$ & 78,6 & 16,7 & 42,9 & 12,0 & 14,3 & 18,5 & 0,0 & 1,8 & b.d. & 0,0 & 14,3 & 2,8 \\
\hline $\begin{array}{l}\text { Zmiany sposobu ogrze- } \\
\text { wania / termomoder- } \\
\text { nizacja }\end{array}$ & b.d. & 66,7 & b.d. & 63,0 & b.d. & 52,8 & b.d. & 4,6 & b.d. & 0,9 & b.d. & 8,3 \\
\hline \begin{tabular}{|l|} 
Alternatywne źródła \\
energii*
\end{tabular} & \multirow{2}{*}{83,9} & 43,5 & \multirow{2}{*}{51,6} & 38,9 & \multirow{2}{*}{24,2} & 52,8 & \multirow{2}{*}{6,5} & 4,6 & b.d. & 0,0 & \multirow{2}{*}{12,9} & 3,7 \\
\hline $\begin{array}{l}\text { Poprawa efektywności } \\
\text { energetycznej* }\end{array}$ & & 56,5 & & 41,7 & & 62,0 & & 4,6 & b.d. & 3,7 & & 1,8 \\
\hline
\end{tabular}

* Alternatywne źródła energii oraz poprawa efektywności energetycznej były potraktowane łącznie w badaniach mających miejsce w 2012 roku, stąd dane dla tych obszarów przedstawiono w tabeli jako jedną wspólną pozycję.

b. d. - brak danych

Źródło: opracowanie własne. 
Jednocześnie warto zauważyć, iż ankietowane gminy wskazywały fundusze unijne jako znaczące źródło finansowania. Ważnym źródłem unijnych środków na ochronę środowiska w województwie śląskim jest Regionalny Program Operacyjny Województwa Śląskiego na lata 2014-2020 (RPO WSL). Planowana wysokość środków unijnych w latach 2014-2020 w RPO wynosi około 3,5 mld euro, z czego na projekty związane z ochroną środowiska przewiduje się wydatkować około 952 mln euro. Jak do tej pory, jest to największy program regionalny kraju.

\section{Podsumowanie}

Planowanie energetyki lokalnej jest korzystne nie tylko ze względu na możliwość zapewnienia bezpieczeństwa energetycznego i ciagłości dostaw, ale również realizacji założeń poprawy efektywności energetycznej i rozwoju odnawialnych źródeł energii w regionie. Aby skutecznie działać w tym zakresie, niezbędne jest: zaangażowanie władz lokalnych i samorządów, opracowanie kompleksowej strategii gospodarki energetycznej na terenie gminy i wyznaczenie ram inwestycji gminnych. Wciąż samorządy lokalne jeszcze nie czują się odpowiedzialne za jakość energii dostarczanej odbiorcom końcowym ani zobowiązane do podejmowania działań na rzecz ograniczania zużycia energii i wzrostu efektywności energetycznej u odbiorców na swoim terenie. Nadal jest niski odsetek gmin, które przyjęły plan zaopatrzenia w energię elektryczną, ciepło i paliwa gazowe oraz wykorzystuja go w praktyce zarządzania. Powodem takiego stanu rzeczy jest zbyt mała świadomość władz samorządowych związana z korzyściami, jakie systemowa polityka energetyczna, prowadzona w sposób rzetelny, może przynieść gminie. Stąd jest nieodzowne przekonanie decydentów o konieczności: racjonalnego kierowania wieloma aspektami gospodarowania energią na szczeblu lokalnym, zrównoważonego planowania sposobów i wielkości wytwarzania oraz przesyłu energii cieplnej i elektrycznej, a także tworzenia warunków harmonijnego rozwoju energetyki odnawialnej, który nie byłby $\mathrm{w}$ sprzeczności $\mathrm{z}$ wymaganiami ochrony środowiska naturalnego i ochrona jego zasobów.

\section{Literatura}

Głębocki K., Herbuś I., 2016, Gminy w nowatorskich platformach wspótpracy ksz̨tattujacych gospodarke energetyczna, Zeszyty Naukowe Politechniki Śląskiej, Seria: Organizacja i Zarządzanie, z. nr 87.

Kubica K., Niska emisja - sprawa aysokiej wagi, http://misja-emisja.pl/knowledgebase/ niska-emisja-sprawa-wysokiej-wagi/ (data wejścia: 10.06.2016).

Lorek A., 2014, Lokalna polityka energetyczna w zrównoważonym rozwoju gmin ślaskich, [w:] Finanse na rzecz zrównoważonego rozzoju. Gospodarka - etyka - środowisko, L. Dziwago, L. Patrzałek (red.), Prace Naukowe Uniwersytetu Ekonomicznego we Wrocławiu, nr 330, Wrocław. 
Lorek E., 2007, Rozwój zrównoważony energetyki w wymiarze międzynarodowym, europejskim $i$ krajonym, [w:] Teoria ipraktyka zrównoważonego rožoju, A. Graczyk (red.), EkoPress, Białystok-Wrocław.

Określenie potencjału energetycznego regionów Polski w zakeresie odnawialnych źródet energii - wnioski dla Regionalnych Programón Operacyinych na okeres programowania 2014-2020, 2011, Ministerstwo Rozwoju Regionalnego, Warszawa.

Program Ochrony Środowiska dla wojewódz̨twa ślaskiego do roku 2019 z. unvaględnieniem perspektywy do roku 2024, 2015, Katowice.

Rynek odnawialnych źródet energii w wojewódz̨twie ślaskim, 2013, Eurocentrum Park Naukowo-Technologiczny, Katowice.

Ustawa z. dnia 10 kwietnia 1997 roku Prawo energetyczne, Dz. U. z 2006 roku, Nr 89, poz. 625 z późn. zm.

Ustawa z. dnia 11 kewietnia 2011 roku o efek.tywności energetycznej, Dz. U. z 2011 roku, Nr 94, poz. $551 \mathrm{z}$ późn. zm.

Założenia programowe do Polityki Gospodarki Niskoemisyjnej dla Wojewódžtwa Ślaskiego, 2016, Zarząd Województwa Śląskiego, Katowice. 